TECHNICAL TRANSACTIONS 5/2017

CZASOPISMO TECHNICZNE 5/2017

MECHANICS

DOI: $10.4467 / 2353737$ XCT.17.074.6431

\begin{abstract}
Zygmunt Dziechciowski (zygmunt.dziechciowski@mech.pk.edu.pl)
Laboratory of Techno-Climatic Research and Heavy Duty Machines,

Faculty of Mechanical Engineering, Cracow University of Technology
\end{abstract}

\title{
Igor Kozłowski
}

GRANA sp. z o.o., Skawina

\section{DETERMINATION OF MINOR LOSS COEFFICIENTS \\ OF AIR BY-PASS BRAKE USED IN PNEUMATIC TUBE SYSTEMS}

OKREŚLANIE WSPÓŁCZYNNIKA STRAT LOKALNYCH DLA HAMULCA

TYPU BY-PASS UŻYWANEGO W SYSTEMACH POCZTY PNEUMATYCZNEJ

\begin{abstract}
The thesis presents the analysis of the pneumatic tube system, one of the solutions in material handling. Contemporary solution components of pneumatic tube systems were presented and described, such as: blowers, diverters, send/receive stations, carriers, air brakes and system couplers. For the purpose of the article, a bypass air brake was built at the Laboratory of Techno-Climatic Research and Heavy Duty Machines of the Cracow University of Technology. which was then tested. The aim of the test was to determine the minor loss coefficient $\zeta$, depending on the degree of the air brake valve override. The measurement results are given in the work.
\end{abstract}

Keywords: materials handling, pneumatic tube systems, minor loss coefficients

\section{Streszczenie}

W artykule przedstawiono analizę systemów poczty pneumatycznej. Opisano współczesne rozwiązania elementów składowych systemów poczty pneumatycznej, takie jak: dmuchawy, zwrotnice, stacje nadawcze i odbiorcze, tuby transportowe, hamulce czy też stacje lącznikowe. Na potrzeby artykułu w Laboratorium Badań Technoklimatycznych i Maszyn Roboczych Politechniki Krakowskiej zbudowano hamulec typu by-pass, który następnie został poddany badaniom w celu wyznaczenia współczynnika strat miejscowych w zależności od stopnia przesłonięcia zaworu hamulca. W pracy zamieszczono wyniki pomiarów.

Słowa kluczowe: transport bliski, poczta pneumatyczna, współczynnik strat lokalnych 


\section{Introduction}

In-house transport as an activity due to the need for relocation of material goods has particularly important role in every company. Therefore, in essence, logistics processes like transferring and delivering small objects in the company are troubling and also time consuming. A solution for this problem is the installation of a pneumatic tube transport. Contemporary pneumatic tube systems are an important element of newest in-house transport because they are the fastest and the most reliable way to deliver small elements within an employment establishment. It is indispensable, especially when it is used for short shipping routes.

Pneumatic tube transport may be a way to improve the uptime by reducing the involvement of employees in the transportation process to a minimum. Small objects like banknotes, documents or test specimens can be send safely and quickly by a pipeline network, not only within the area of one building, but also beyond.

At the Laboratory of Techno-Climatic Research and Heavy Duty Machines of the Cracow University of Technology, works in the aspect of improving the functionality of this mode of transport are carried out. Leading the research, staff of the Laboratory can make use of a model of a pneumatic tube system located in Institute's laboratory. This model is still developed, and in the future, it will be used to test new solutions, system components, on which work is carried out.

\section{Contemporary pneumatic tube systems}

\subsection{Review of contemporary pneumatic tube systems applications}

Nowadays, the pneumatic post is most often applied in healthcare facilities (hospitals, pharmacies, blood centre), and also in places where there is a necessity of transporting large amounts of cash, such as superstores, casinos, exchange offices or banks. Pneumatic tube systems are used wherever they can bring tangible benefits.

In some cases, pneumatic tubes can have the same tasks (e.g. transport of documents or keys); however, the specific functions will depend on the place of application. In all of the locations, pneumatic tubes work on the same operating principle.

\subsection{Structure of the pneumatic tube system}

An exemplary of the pneumatic tube scheme with a description of the components is shown in Fig. 1. The main components of the system include: blowers, diverters, send/ receive stations, carriers, bypass air brakes and couplers. The elements are connected by tubes, which are divided to air tubes and transporting tubes. Carriers travel through transporting tubes. Air tubes connect the blower with other components, but carries do not travel through air tubes. The movement of the tube is caused by a pressure difference in the pipe, which is made by the blower. 


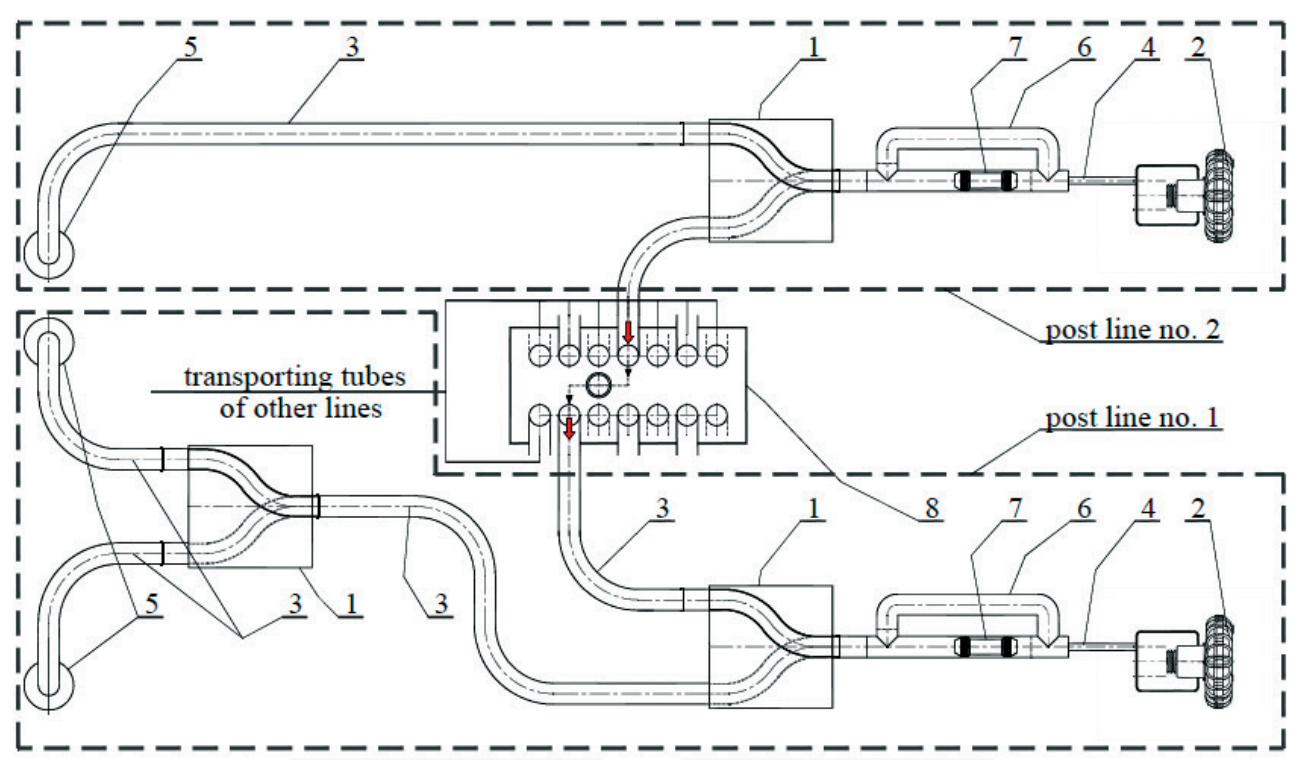

Fig. 1. Scheme of multi-line pneumatic tube with linear coupler. 1 - diverter, 2 - blower, 3 transporting tube, 4 - air tube, 5 - send/receive station, 6 - bypass air brake, 7 - carrier, 8 - linear coupler

Pneumatic tubes are used in many industries, so they must be appropriately adapted. For physical properties of shipments adapts: construction of the carrier, cruising speed, a method of inhibiting the carrier and a construction of receiving station. All of this must be taken into consideration to ensure the main task: sending the requested number of consignments at a specific time between senders. A pneumatic tube system is constructed as a single-system, powered by one or two blowers (one is used to generate a pressure and the other to generate a vacuum) or a multiline system, where a linear coupler or a series of diverters are used to split the tube.

\subsection{Overview of pneumatic tube system components}

\subsubsection{Blowers}

The driving force of a pneumatic tube system is the blower. It is the fans that cause the carriers to move through the tubes. Examples of this device are shown in Figs. 2 and 3. By creating a difference in air pressure between the two ends of the system, the blower effectively sucks or blows the carrier through the pneumatic tubes. In case of multi-line systems, which use more than one blower, they are often located in a separate room. The most common type is the three-phase side channel blower, which is shown in Fig. 2. 


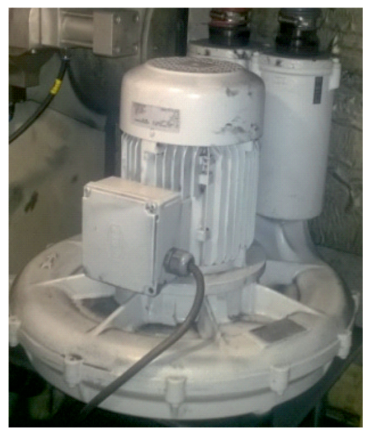

Fig. 2. Typical three-phase side channel blower

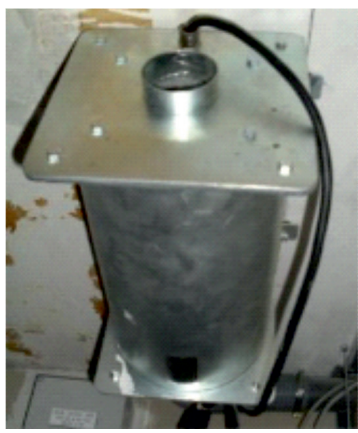

Fig. 3. Type of blower: Drivagg Stal D 1X Dubbel 1000W by Aerocom [2]

\subsubsection{Diverters}

A diverter makes it possible to branch out from the main transmission tube run to stations and it also gives the possibility to connect individual lines together. The diverter usually is constructed as two or three -ways, but there are also known technical solutions of a diverter, such as four, five or six - ways. It depends on the number of required ports. An example of the 3-ways diverter is shown in Fig. 4.

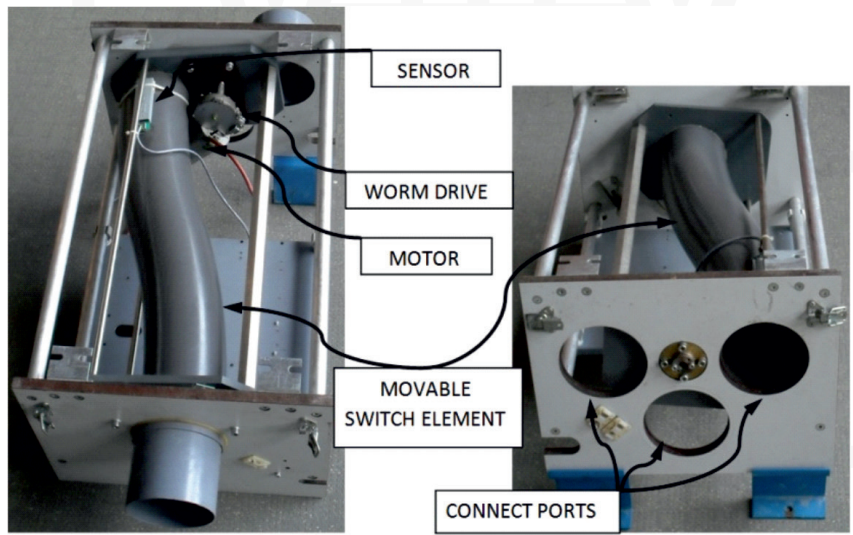

Fig. 4. The 3-ways of diverter NW110 by Telecom [2]

A characteristic feature of a contemporary diverter is formed in the s-shaped pipe, which is aligned with the correct port on the opposite end of the diverter. The diverter has a single motor, mounted directly onto the drive shaft of the rotating s-shaped tube. It is electronic monitoring and remote operated. The diverter can be mounted either horizontally or vertically.

These devices are often used on the air duct, connected to the blower in order to change the system from blow to suck and conversely. This solution allows to use only one blower, either for the sucking mode or the blowing mode. A set of blower and diverter for changing the operating mode is shown in Figs. 5 and 6. 


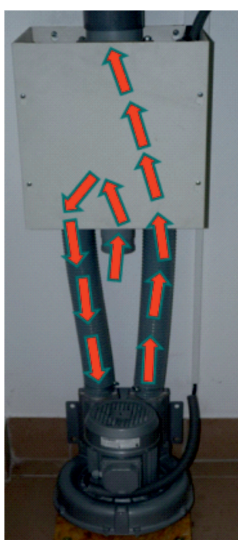

Fig. 5. The drive set - blowing mode [2]

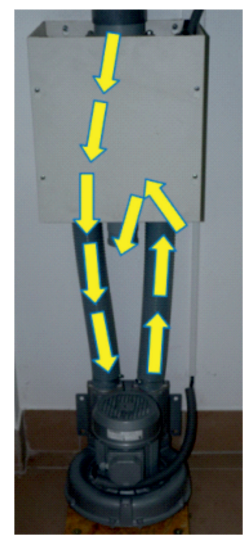

Fig. 6. The drive set - sucking mode [2]

\subsubsection{Send and receive stations}

Pneumatic tube stations are elements which are used to send and receive carriers. Stations are divided into: programmable send/receive stations (initial/end and send-through stations), slide sleeve stations and auto unload stations.

Simple slide sleeve stations (without control panel) are used as initial or end stations. The carrier of this station is delivered from the top. It contains sleeve founded on the tube and separate send-button next to it. The arriving carrier activates a tube switch, which switches off the system. It is the most common station used in cash pneumatic tube systems. The slide sleeve station is presented in Fig. 7.

The more advanced send/receive stations have separate tubes for insertion and ejection of the carrier. They are often used as send-through stations. It has the open storage facility (for example the basket), situated below the station. An example of this type of station is shown in Fig. 8.

Stations of this type are equipped with a control panel. The user can set special functions, such as shipment priority or request of slow carrier transport. If need, carrier can only be removed from the station when a security code is entered. In addition, stations can archive information, such as: sending and receiving time, destination place, ID of sender and receiver etc. Stations can be equipped with a friendly touch HMI panel. The station shown in fig. 8 is located in a ,show room” of the Transmarket company (Poland).

An example of innovation in pneumatic tube system are the Auto Unload Stations. It is presented in Fig. 9. Stations of this type are used in St. Barbara Regional Specialist Hospital No. 5 in Sosnowiec (Poland). Opening and unloading of carriers is done automatically. After unloading, the carrier automatically goes back to the sender. It helps labs to rationalise processes for higher throughput and maximum efficiency. Due to the fully automatic opening and closing mechanism, the samples are ejected automatically. However, such a system has disadvantages. Firstly, it requires special carriers with automatic opening mechanism. Secondly, the transported cargo can get stuck inside the carrier (e.g. plastic bags), so cannot fall out in destination point. 


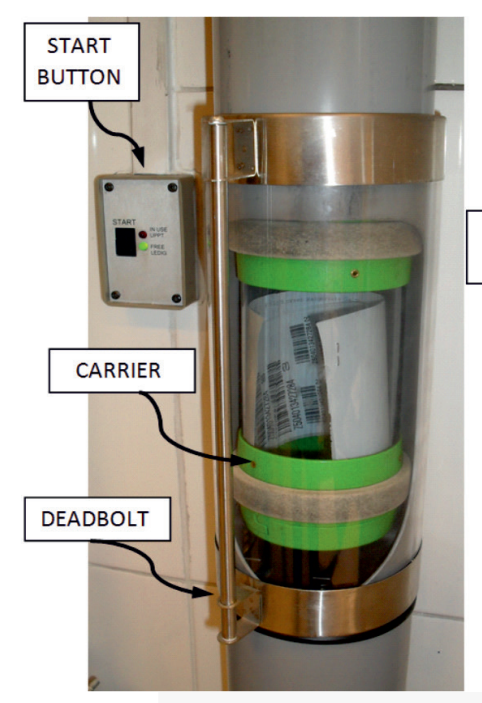

Fig. 7. Slide sleeve station by Hörtig [2]

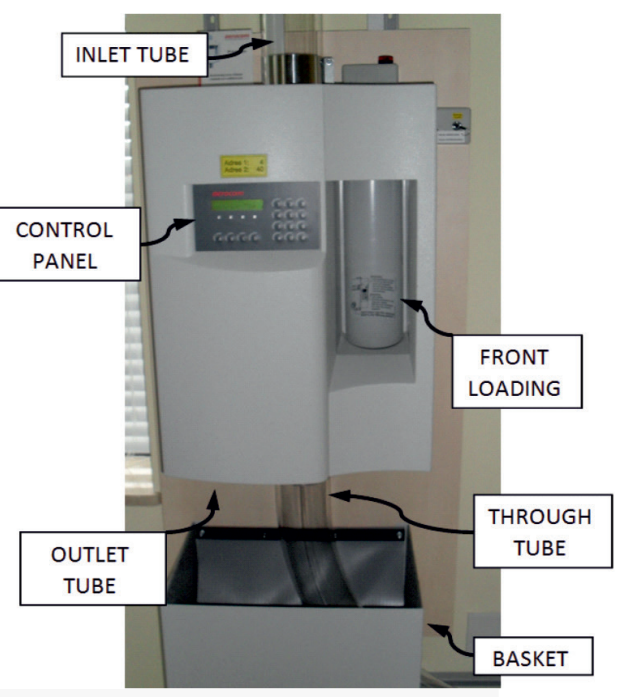

Fig. 8. Station „Premium” by Aerocom [2]

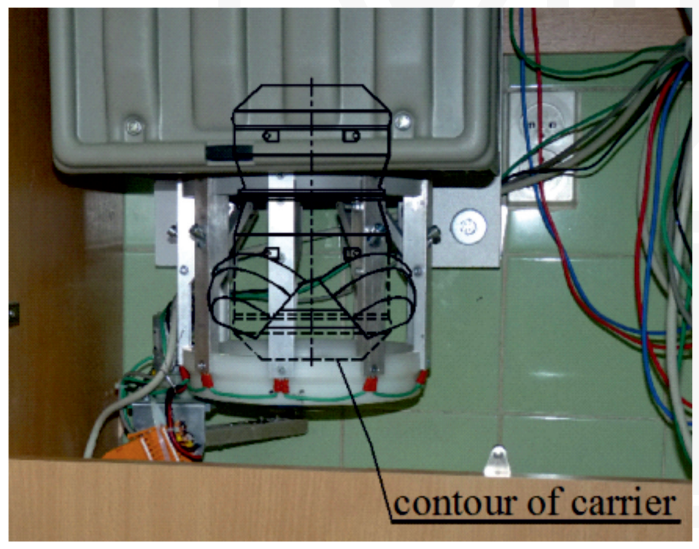

Fig. 9. The auto unload station by Sumetzberger [2]

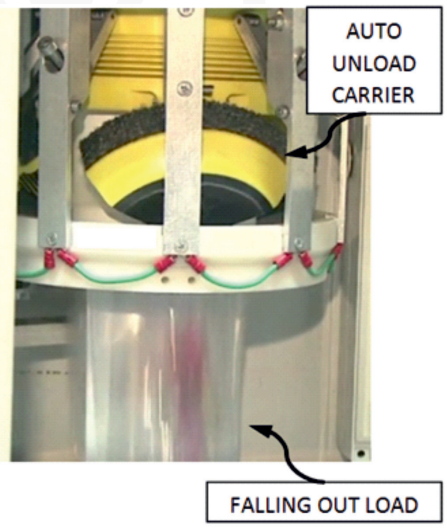

Fig. 10. The auto unload station - unloading the carrier [2]

\subsubsection{Carriers}

Carriers are cylindrical containers used for transporting various cargos inside of them. Carriers are very varied (due to the length, diameter, way of loading, destination) depending on send of item inside them. Carrier consists of a body (mostly transparent), openable lids and sealing rings. Loading of the carrier may be carried out on the side or axially. Examples of carriers are shown in Figs. 11 and 12. 


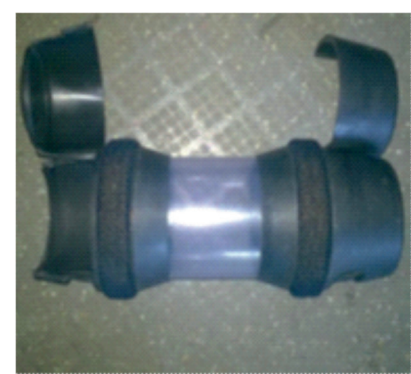

Fig. 11. Example of carrier [3]

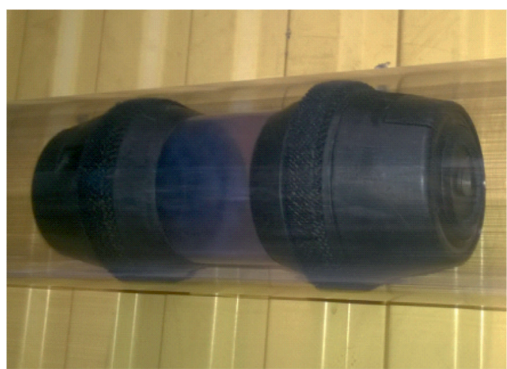

Fig. 12. Carrier during transport [3]

An innovative solution is an auto-unload carrier, which operates with auto-unload stations (see Figs. 9 and 10). Carriers of this type are used in St. Barbara Regional Specialist Hospital No. 5 in Sosnowiec (Poland). An example of the auto-unload carrier is shown in Fig. 13.

Carriers have different lengths and diameters adapted to the cross section of tubes. The external shape of the container should guarantee its good entering to the tube's bends. The formula for calculating the maximum outer diameter of the carrier is given by (1).

$$
d_{\max }=D_{w}+R \cdot\left(\sqrt{1-\frac{1}{4} \cdot \frac{L^{2}}{R^{2}}}-1\right)[m]
$$

where,

$D_{w}$ - outer diameter of tube $[\mathrm{m}]$,

$R$ - radius of the axis arc $[\mathrm{m}]$,

$L$ - the distance between the centre of sealing rings $[\mathrm{m}]$.
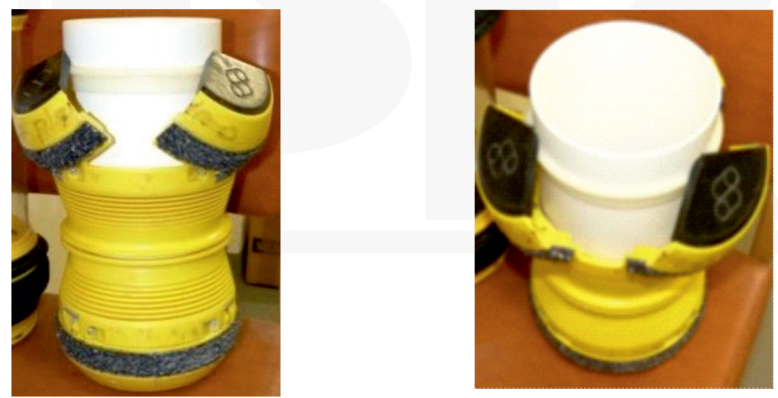

Fig. 13. The auto-unload carrier by Sumetzberger [2]

\subsubsection{Brakes}

During the transportation process, it is often necessary to stop the carrier. This will be done in the case of getting the carrier to the destination station or changing the transport route. Air brakes are used to stop the carriers.

An example of the air brake - Bypass Air Brake is shown in Fig. 14. 

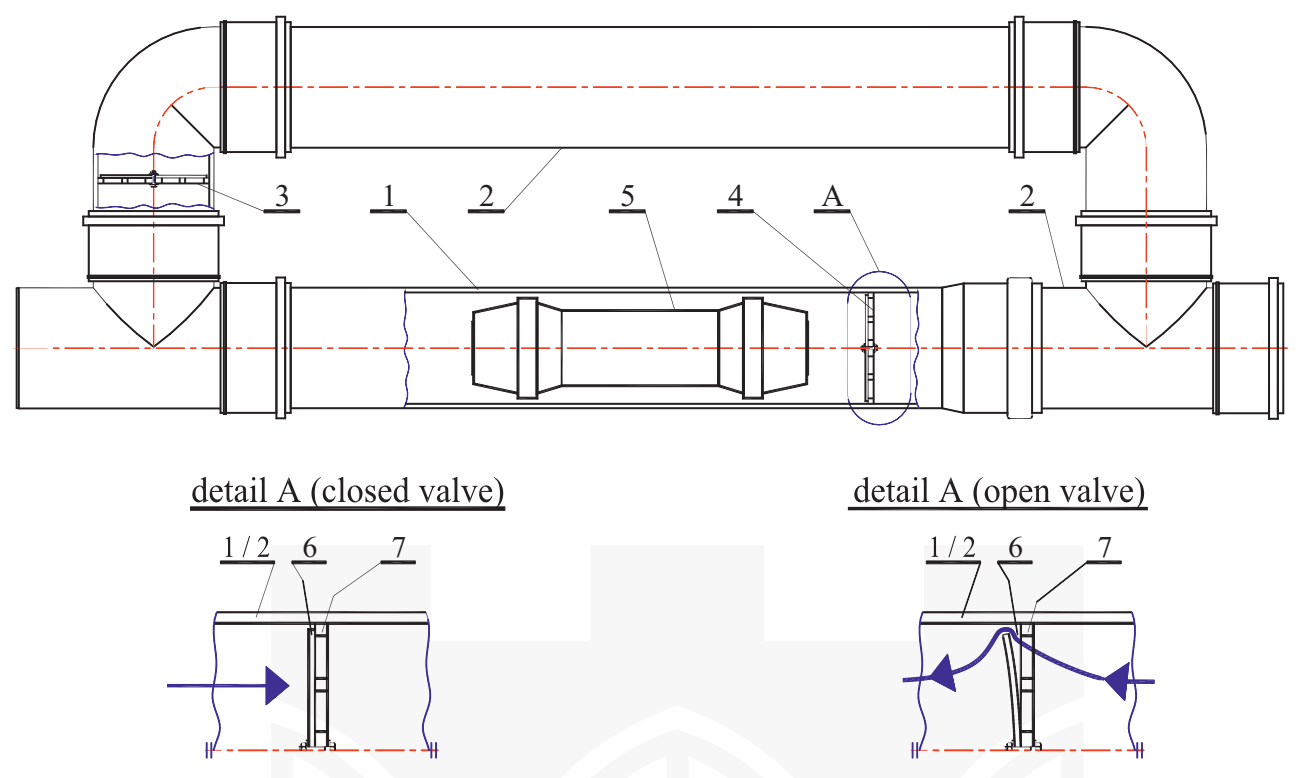

Fig. 14. Bypass Air Brake: 1 - transporting tube, 2 - air tube, 3 and 4 - one-way air valves, 5 - carrier, 6 - movable rubber gasket, 7 - value face

The bypass air brake consists of two ducts and two one-way air valves. The main elements of the bypass air brake are one-way air valves. The construction and operating principles of the bypass air brake are shown in Fig. 14 .

These one-way valves are located inside the tubes in such a way that the state of the valve (open/closed) depending on the blower running (suction or pressing).The air can flow by the transporting (usually transparent) tube or by the bypass air tube. If one valve is open, the other is automatically closed. When a carrier is sucked by the blower, the air will go through the bypass pipe. If the carrier arrives to the carrying tube, the blower is switched off. The carrier will be stopped by a pneumatic spring in the transporting tube. The rest of the air will flow through the bypass tube and will no longer affect the carrier. If the blower blows the air, the position of the valves will change. The valve of bypass is closed and the air will blow the carrier to the destination station.

Another type of brakes used in the send/receive station is shown in Fig. 15. The pictures illustrated the principle of its operation. Brakes like these consist of transporting no-through tube. At the end of the brake tube, a bumper could be installed (Fig. 15A) or a bumper and the one-way air valve (Fig. 15B). The one-way air valve is the same valve, which is shown in Fig. 14. Outside of the tube, an outer cover with perforation is mounted. Compressed air supplied by a blower pushes the carrier inside of the station. The carrier will be stopped by the air buffer (pneumatic spring) produced inside the tube. Excess air flows through the outer cover perforation (Fig. 15A) or by the leak or special holes (Fig. 15B). 
A)

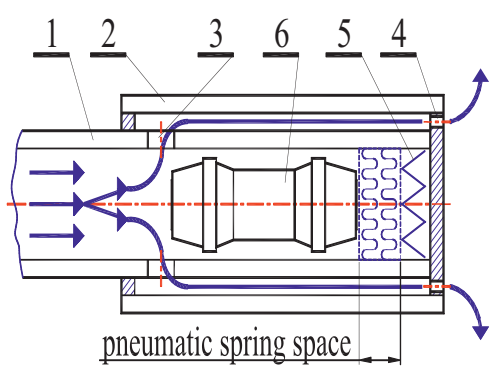

B)

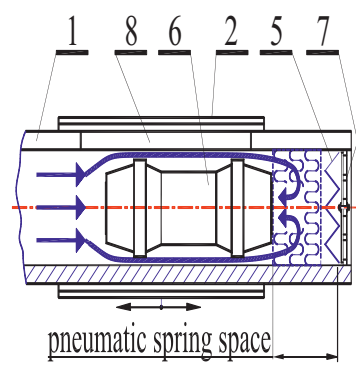

Fig. 15. Scheme of brakes inside send/receive station: 1 - transporting tube, 2 - outside cover, 3 and 4 - holes for the excess air, 5 - bumper, 6 - carrier, 7 - one-way air valve, 8 - load opening

\subsubsection{System couplers}

The size of the system, length of the route, building configurations or send frequency requirements may make it necessary to split a tube system into independently operating couples, particularly lines or zones of the tube system. The following coupling methods are applied: central coupling by diverters, central coupling by a coupler.

In case of coupling lines by diverters, carriers are automatically transported from zone to zone through a coupling diverter system. A scheme of such a solution is shown in Fig. 16. A disadvantage of this solution is the fact that after sending a carrier, the entire pneumatic tube line becomes a kind of warehouse for the sent carrier, which disables the line for another carrier despatched by the tube system. Only a delivery of the carrier to the destination point unlocks the pneumatic tube system. This may be avoided by the use special send/receive stations with an ability to store the carriers.

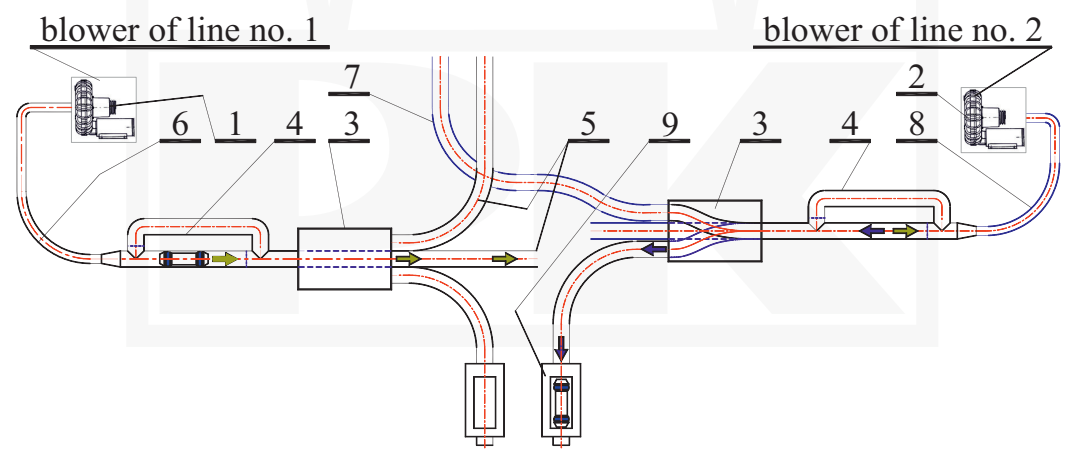

Fig. 16. Pneumatic tube lines connected by diverters: 1 and 2 - blower, 3 - diverter, 4 - air bypass brake, 5 and 7 - carrying tube, 6 and 8 - air tube, 9 - send/receive station

Couplers does not have this disadvantages. There are two types of couplers: linear type and carousel type. They are used for high-capacity tube systems and large numbers of stations where the system has to be split into separate, but fully coupled zones. The advantage of tube system coupler is that a carrier can be in transit in each line / zone simultaneously and carriers can be sent from zone to zone. The unit can function as temporary storage, thus waiting times 


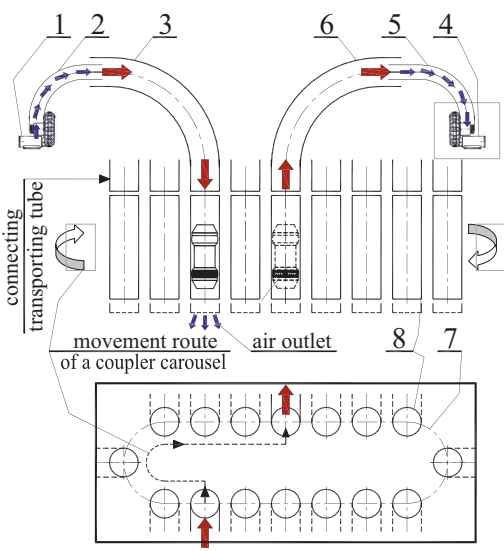

Fig. 17. Scheme of a carousel coupler: 1 and 4 - blower, 2 and 5 - air tube, 3 and 6 - carrying tube, 7 - carousel guide, 8 - temporary storage for carriers [2]

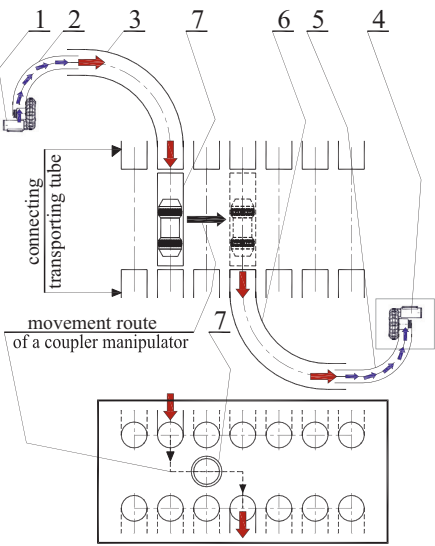

Fig. 18. Scheme of a linear coupler: 1 and 4 - blower, 2 and 5 - air tube, 3 and 6 - carrying tube, 7 - manipulator [2]

for the important shipments are avoided. Schemes of linear couplers, both linear and carousel, are shown in Fig. 17 and 18.

\section{Research}

The most important task of the pneumatic tube system is to ensure that all sent packages are delivered to users within the time specified. To provide the correct fulfilment of the main task, the appropriate drive must be selected. In order to do this, it is necessary to know the location of each element (e.g. send/receive stations or blowers), length of the routes and the number of "obstacles" in the designed installation. All of this allows to perform calculations in terms of selection of a suitable drive power. In the calculations, the pressure losses occurring in the system need to be known. Pressure losses are associated with locally occurring "obstacles", such as changes of the tube diameter (reducer or sudden enlargement), changes of the flow direction (elbows), pipe tee (with three sockets), and other elements mounted in the pipeline (e.g. valves, taps), inlets and outlets of the pipeline, as well as the presence of elements closely associated with the pneumatic tube system, such as diverters or bypass air brakes. For the determination of pressure loss in the system, the minor loss coefficients of the individual elements of the design installation are required.

For conventional hydraulic or pneumatic installations, the value of minor loss coefficients can be found in the literature (e.g. [4]). However, there are no data on this topic in relation to modern pneumatic tube system elements. Table 1 shows values of minor loss coefficients for elements of capsule pipelines used in the 70 s of the $20^{\text {th }}$ century and earlier. Considering the need to fill those deficiencies, the authors performed experimental measurement and calculations of this parameter for the selected element. 
Table 1. The values of minor loss coefficients $\zeta$ for some elements of pneumatic tube system in the $70 \mathrm{~s} 20^{\text {th }}$ century and earlier [5]

\begin{tabular}{|c|c|}
\hline Local resistance & $\zeta$ \\
\hline Clearance in the tubes & 0.01 \\
\hline Sending station & $2-3$ \\
\hline Automatic diverter & $4-5$ \\
\hline Tube switch & 0.05 \\
\hline Bend & 0.05 \\
\hline
\end{tabular}

In the present study, one of the most frequently occurring element in modern pneumatic tube system installations - bypass air brake, has been tested. With the experimental method, the authors determined the value of pressure drop and the working medium flow speed in two cases: the air suction and blowing out. Then, they made the relevant calculations in order to determine the minor loss coefficients $\zeta$.

\section{Object of study- the bypass air brake}

The tested bypass air brake was built at the Laboratory of Techno-Climatic Research and Heavy Duty Machines of the Cracow University of Technology in Poland. The object of the study is shown in Fig. 19. The construction of the air brake and its principle of operation is presented in Chapter 2.3.5.

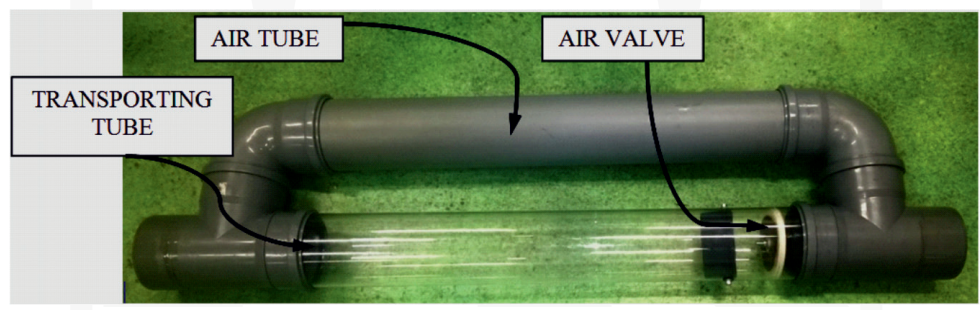

Fig. 19. The tested object - bypass air brake

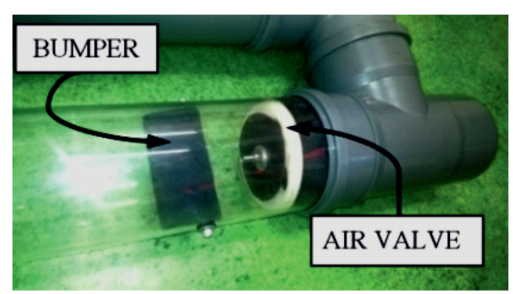

Fig. 20. The bumper and the one-way air valve inside the transparent tube of the brake

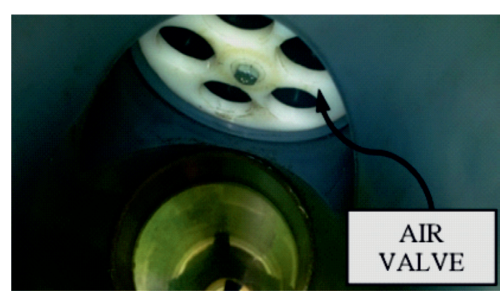

Fig. 21. The one-way air valve mounted in the elbow 
The air brake has been tested for five different operating conditions. Operating conditions were established by changing the diameter of the movable rubber gasket of the air valve (Fig $14 \mathrm{~A}$ and $14 \mathrm{~B}$, detail A) in range of $\phi 0.0 \mathrm{~mm}$ (without gasket) to $\phi 95 \mathrm{~mm}$. For each condition, measurements of static pressure and speed of air flow were performed. Air valves mounted in the bypass air brake are show in Figs. 20 and 21.

The measurement process was made for different diameters of rubber gasket: $\phi 0.0 \mathrm{~mm}$ (without gasket), $\phi 55 \mathrm{~mm}, \phi 75 \mathrm{~mm}$ and $\phi 95 \mathrm{~mm}$. Only the diameter of the rubber gasket of the air valve installed in the transparent tube of the brake was changed.

The one-way air valve prepared for installation in the transporting tube is shown on Figs. 22 and 23.

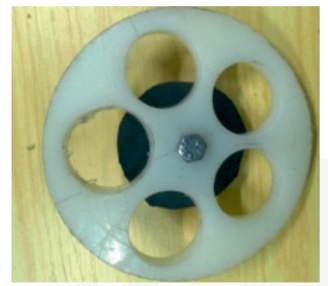

Fig. 22. The air valve with rubber gasket diameter of $\phi 55 \mathrm{~mm}$

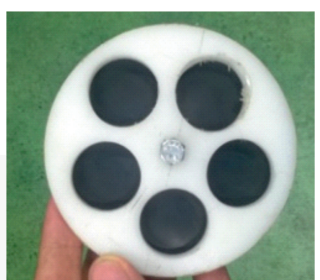

Fig. 23. The air valve with rubber gasket diameter of $\phi 95 \mathrm{~mm}$

\section{Determination of minor losses coefficients for bypass air brake}

\subsection{Research methodology}

The research methodology has been developed based on [6] and [7].The local energy loss $h_{s t r}$ can be calculated by the formula (2), for various types of the hydraulic obstacle.

$$
h_{s t r}=\zeta \frac{v_{s r}{ }^{2}}{2 \cdot g}[m]
$$

where:

$h_{s t r}-$ amount of pressure loss, $[\mathrm{m}]$,

$\zeta$ - minor loss coefficients, [-],

$v_{s r}-$ average air velocity, $[\mathrm{m} / \mathrm{s}]$,

$g-$ gravitational acceleration, $\left[\mathrm{m} / \mathrm{s}^{2}\right]$.

After transformation of equation (2), it could be utilised to calculate the value of minor loss coefficients $\zeta$, which is presented by (3).

$$
\zeta=\frac{2 \cdot g \cdot h_{s t r}}{v_{s r}{ }^{2}}[-]
$$




\subsection{Measurement of airflow velocity}

Depending on the flow of the operating medium, a differential velocity profile in the tube is obtained. The value of the velocity changes, e.g. depending on the position with respect to the obstacle. In order to determine the distribution of air velocity values, the measurement procedure was performed in the air duct. The measurements of the velocity were conducted before and after the bypass air brake for two operating modes: suction and blowing. This was caused by the fact that in order to determine the value of the minor loss coefficients $\zeta$ of the tested element, the difference of the average value of the air velocity of both sides of the tested element is required (before and after the bypass air brake).

The air velocity values were measured by pressure and velocity meter THERM 2295-2B equipped with the Prandtl probe (tube diameter of $\phi 8 \mathrm{~mm}$ ).

The cross-section of the air tube was divided into two measuring surfaces A-A and B-B shown in Fig. 24.

In order to measure the average value of the velocity of the turbulent air flow, the Prandtl probe were used. During the measurement process, according to [8], the cross section of the tube was divided into parts of equal surface areas.

In Fig. 24, the division of the cross section of the circular tube into three parts is presented, where the measuring points were marked. The measurements of the air velocity were carried out in six points in each of cross sections (A-A and B-B - see Fig. 24).

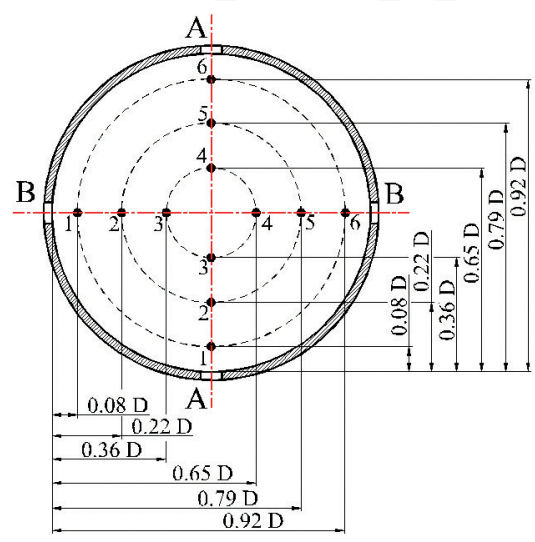

Fig. 24. Location of the measurement points in the air duct depending on the cross-section (D - diameter of a tube) [8]

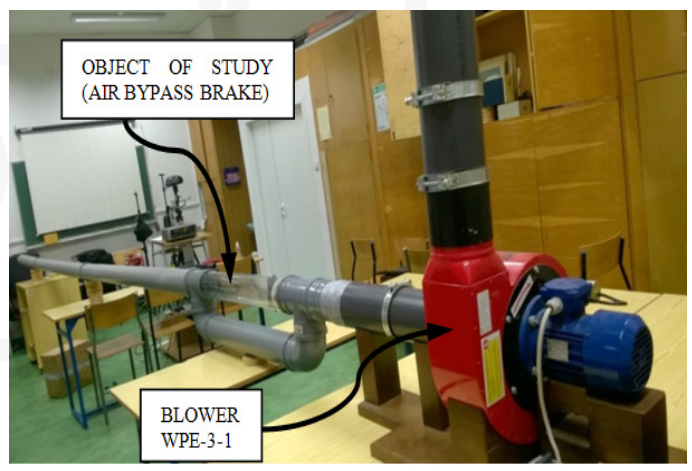

Fig. 25. View of measurement stand with tested element

The average value of the air velocity in every part is calculated from the formula (4), separately for each cross section. Value vi is calculated as the arithmetic mean of the air flow velocity for each circular part. 


$$
v_{s r}=\frac{1}{n} \cdot \sum_{i=1}^{n} v_{i}[m / s]
$$

were:

$v_{i}$ - air velocity in circular part, $[\mathrm{m} / \mathrm{s}]$,

$n$ - number of measurement points.

\subsection{The test stand}

Measurement conditions that were made are defined in [6]. The length of preliminary section $L$ from the inlet to the tube of working medium to the location of steady flow area (turbulent flow) is calculated from the formula (5)

$$
L=(7.88 \cdot \log \operatorname{Re}-4.35) \cdot D[m]
$$

where:

Re-Reynolds number, [-],

$D$ - inner diameter of the tube, $[\mathrm{m}]$.

The test stand consisted of a pipeline with a diameter of $110 \mathrm{~mm}$. This allowed to obtain the required length $L$ of preliminary section. The test stand was supplied using radial fan Klimawent WPE-3-1 power of 370 W. View of test stand with tested element is shown in Fig. 25.

\subsection{The measurements results}

\subsubsection{Results for measurements of air flow velocity}

The measurements were conducted in the area before and after the bypass air brake for two operating modes: suction and blowing (distance between measurement areas according to the [8]). The air velocity was measured using the apparatus THERM 2295-2B equipped with the Prandtl probe. The results of air speed measurements for different measuring points (see Fig. 24) are presented in the form of tabular summaries (Table 2-5).

Table 2. The measurements results of air flow velocity for test element in case of measurement before bypass air

\begin{tabular}{|c|c|c|c|c|c|c|c|}
\hline \multirow[t]{2}{*}{ Measuring cases } & \multirow[t]{2}{*}{ Surface } & \multicolumn{6}{|c|}{$\begin{array}{l}\text { The value of the air flow velocity } v[\mathrm{~m} / \mathrm{s}] \text { in the measuring point } \\
\text { accord. to Fig. } 26\end{array}$} \\
\hline & & 1 & 2 & 3 & 4 & 5 & 6 \\
\hline \multirow{2}{*}{ Without the one-way valve } & A-A & 21.5 & 23.7 & 24.1 & 24.1 & 23.7 & 21.5 \\
\hline & B-B & 21.0 & 24.3 & 25.5 & 25.5 & 24.3 & 21.0 \\
\hline \multirow{2}{*}{$\begin{array}{l}\text { One-way air valve without } \\
\text { movable, rubber gasket }\end{array}$} & A-A & 16.7 & 18.1 & 19.1 & 19.1 & 18.1 & 16.7 \\
\hline & B-B & 16.4 & 18.4 & 19.7 & 19.7 & 18.4 & 16.4 \\
\hline
\end{tabular}
brake for suction operating mode depending on the brake valve status 


\begin{tabular}{|c|c|c|c|c|c|c|c|}
\hline $\begin{array}{c}\text { One-way air valve with rubber } \\
\text { gasket of diameter } \varphi 55[\mathrm{~mm}]\end{array}$ & A-A & 8.9 & 10.1 & 11.0 & 11.0 & 10.1 & 8.9 \\
\hline Bne-B & 8.7 & 9.8 & 10.7 & 10.7 & 9.8 & 8.7 \\
\hline gasket of diameter $\varphi 75[\mathrm{~mm}]$ & A-A & 7.6 & 8.4 & 9.1 & 9.1 & 8.4 & 7.6 \\
\hline One-way air valve with rubber & A-A & 7.8 & 8.6 & 8.9 & 8.9 & 8.6 & 7.8 \\
gasket of diameter $\varphi 95[\mathrm{~mm}]$ & B-B & 6.6 & 7.4 & 8.0 & 8.0 & 7.4 & 6.8 \\
\hline
\end{tabular}

Table 3. The measurements results of air flow velocity for test element in case of measurement after bypass air brake for suction operating mode depending on brake valve status

\begin{tabular}{|c|c|c|c|c|c|c|c|}
\hline \multirow[t]{2}{*}{ Measuring cases } & \multirow[t]{2}{*}{ Surface } & \multicolumn{6}{|c|}{$\begin{array}{l}\text { The value of the air flow velocity } v \\
{[\mathrm{~m} / \mathrm{s}] \text { in the measuring point accord. }} \\
\text { to Fig. } 26\end{array}$} \\
\hline & & 1 & 2 & 3 & 4 & 5 & 6 \\
\hline \multirow{2}{*}{ Without the one-way valve } & A-A & 21.8 & 22.5 & 23.2 & 23.2 & 22.5 & 21.8 \\
\hline & B-B & 21.5 & 22.3 & 24.1 & 24.1 & 22.3 & 21.5 \\
\hline \multirow{2}{*}{ One-way air valve without movable, rubber gasket } & A-A & 15.3 & 17.4 & 18.0 & 18.0 & 17.4 & 15.3 \\
\hline & B-B & 16.1 & 17.2 & 18.2 & 18.2 & 17.2 & 16.1 \\
\hline \multirow{2}{*}{ One-way air valve with rubber gasket of diameter $\varphi 55[\mathrm{~mm}]$} & A-A & 7.4 & 8.1 & 9.2 & 9.2 & 8.1 & 7.4 \\
\hline & B-B & 7.8 & 8.2 & 9.5 & 9.5 & 8.2 & 7.8 \\
\hline \multirow{2}{*}{ One-way air valve with rubber gasket of diameter $\varphi 75[\mathrm{~mm}]$} & A-A & 5.9 & 6.5 & 8.1 & 8.1 & 6.5 & 5.9 \\
\hline & B-B & 6.2 & 6.6 & 7.9 & 7.9 & 6.6 & 6.2 \\
\hline \multirow{2}{*}{ One-way air valve with rubber gasket of diameter $\varphi 95[\mathrm{~mm}]$} & A-A & 5.2 & 5.8 & 6.2 & 6.2 & 5.8 & 5.2 \\
\hline & B-B & 5.1 & 5.7 & 6.3 & 6.3 & 5.7 & 5.1 \\
\hline
\end{tabular}

Table 4. The measurements results of air flow velocity for test element in case of measurement before bypass air brake for blowing operating mode depending on brake valve status

\begin{tabular}{|c|c|c|c|c|c|c|c|}
\hline \multirow{2}{*}{ Measuring cases } & \multirow{3}{*}{ Surface } & \multicolumn{3}{|c|}{ The value of the air flow velocity $v[\mathrm{~m} / \mathrm{s}]$} \\
in the measuring point accord. to Fig. 26
\end{tabular}


Table 5. The measurements results of air flow velocity for test element in case of measurement after bypass air brake for blowing operating mode depending on brake valve status

\begin{tabular}{|c|c|c|c|c|c|c|c|}
\hline \multirow[t]{2}{*}{ Measuring cases } & \multirow[t]{2}{*}{ Surface } & \multicolumn{6}{|c|}{$\begin{array}{l}\text { The value of the air flow velocity } V \\
{[\mathrm{~m} / \mathrm{s}] \text { in the measuring point accord. }} \\
\text { to Fig. } 26\end{array}$} \\
\hline & & 1 & 2 & 3 & 4 & 5 & 6 \\
\hline \multirow{2}{*}{ Without the one-way valve } & A-A & 22.8 & 23.5 & 25.2 & 25.2 & 23.5 & 22.8 \\
\hline & B-B & 22.5 & 23.8 & 25.1 & 25.1 & 23.8 & 22.5 \\
\hline \multirow{2}{*}{ One-way air valve without movable, rubber gasket } & A-A & 17.3 & 18.2 & 19.8 & 19.8 & 18.2 & 17.3 \\
\hline & B-B & 17.5 & 18.4 & 19.6 & 19.6 & 18.4 & 17.5 \\
\hline \multirow{2}{*}{ One-way air valve with rubber gasket of diameter $\varphi 55[\mathrm{~mm}]$} & A-A & 8.4 & 9.7 & 10.6 & 10.6 & 9.7 & 8.4 \\
\hline & B-B & 8.8 & 9.9 & 10.8 & 10.8 & 9.9 & 8.8 \\
\hline \multirow{2}{*}{ One-way air valve with rubber gasket of diameter $\varphi 75[\mathrm{~mm}]$} & A-A & 7.9 & 8.7 & 9.8 & 9.8 & 8.7 & 7.9 \\
\hline & B-B & 7.8 & 8.9 & 9.9 & 9.9 & 8.9 & 7.8 \\
\hline \multirow{2}{*}{ One-way air valve with rubber gasket of diameter $\varphi 95[\mathrm{~mm}]$} & A-A & 6.5 & 7.4 & 7.9 & 7.9 & 7.4 & 6.5 \\
\hline & B-B & 6.8 & 7.6 & 8.1 & 8.1 & 7.6 & 6.8 \\
\hline
\end{tabular}

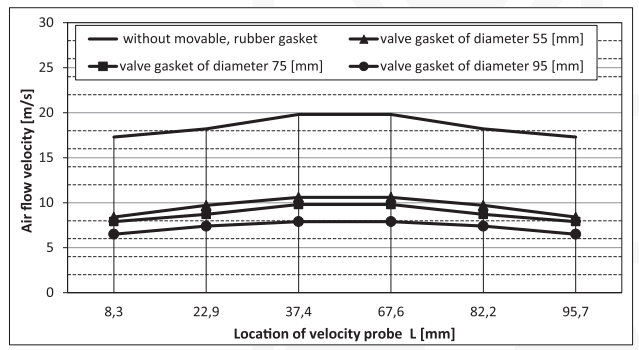

Fig. 26. The air flow velocity distribution in the cross section before the bypass air brake in surface A-A for blowing operating mode

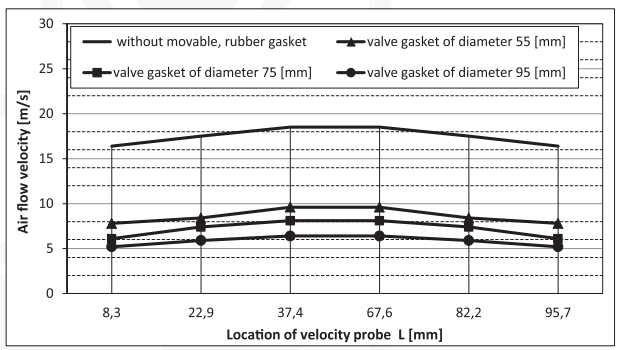

Fig. 27. The air flow velocity distribution in the cross section after the bypass air brake in surface A-A for blowing operating mode

Figs. 26 and 27 shows the air flow velocity distribution in the cross section, adequately before and after bypass air brake for surface A-A for blowing operating mode. The drawings were created on the basis the values contained in the Table 2-5.

\subsubsection{Measurement results for static pressure}

Measurements of the difference in the static pressure were conducted between two measurements points, before and after the bypass air brake (distance between the measurement points defined in [6]). The static pressure values were measured using manometer Abatronic $\mathrm{AB}$ 8890. Measurement results conducted for two operating modes: suction and blowing, are shown in Table 6. 
Table 6. The measurement of difference static pressure for bypass air brake for suction operating mode $\left[\mathrm{mm} \mathrm{H}_{2} \mathrm{O}\right]$

\begin{tabular}{|c|c|c|c|c|c|}
\hline \multirow{2}{*}{$\begin{array}{c}\text { Operating mode of } \\
\text { blower }\end{array}$} & \multicolumn{5}{|c|}{ Values of the measurement of difference static pressure $\Delta p$ [mm $\left.\mathrm{H}_{2} \mathrm{O}\right]$} \\
\cline { 2 - 6 } & $\begin{array}{c}\text { Without one } \\
\text { way valve }\end{array}$ & $\begin{array}{c}\text { Valve without } \\
\text { movable, } \\
\text { rubber gasket }\end{array}$ & $\begin{array}{c}\text { Valve with } \\
\text { rubber gasket } \\
\text { of diameter } \\
\phi 55[\mathrm{~mm}]\end{array}$ & $\begin{array}{c}\text { Valve with } \\
\text { rubber gasket } \\
\text { of diameter } \\
\phi 75[\mathrm{~mm}]\end{array}$ & $\begin{array}{c}\text { Valve with } \\
\text { rubber gasket } \\
\text { of diameter } \\
\phi 95[\mathrm{~mm}]\end{array}$ \\
\hline Blowing & 24 & 54 & 64 & 78 & 80 \\
\hline Suction & 31 & 58 & 68 & 78 & 80 \\
\hline
\end{tabular}

\subsection{Calculation of minor loss coefficients $\zeta$}

Based on the measurements shown in Table 2-6 and using formulas (2-4), the minor loss coefficients $\zeta$ were determined. Calculated values are shown in table 7.

Table 7. Values of minor loss coefficients $\zeta[-]$

\begin{tabular}{|c|c|c|c|c|c|}
\hline \multirow{2}{*}{$\begin{array}{c}\text { Operating mode of } \\
\text { blower }\end{array}$} & \multicolumn{5}{|c|}{ Values of minor loss coefficients $\zeta[-]$} \\
\cline { 2 - 6 } & $\begin{array}{c}\text { Without one } \\
\text { way valve }\end{array}$ & $\begin{array}{c}\text { Valve without } \\
\text { movable, } \\
\text { rubber gasket }\end{array}$ & $\begin{array}{c}\text { Valve with } \\
\text { rubber gasket } \\
\text { of diameter } \\
\phi 55[\mathrm{~mm}]\end{array}$ & $\begin{array}{c}\text { Valve with } \\
\text { rubber gasket } \\
\text { of diameter } \\
\phi 75[\mathrm{~mm}]\end{array}$ & $\begin{array}{c}\text { Valve with } \\
\text { rubber gasket } \\
\text { of diameter } \\
\phi 95[\mathrm{~mm}]\end{array}$ \\
\hline Blowing & 0.06 & 0.11 & 0.21 & 0.33 & 0.45 \\
\hline Suction & 0.07 & 0.12 & 0.35 & 0.43 & 0.54 \\
\hline
\end{tabular}

\section{Conclusions}

In recent years, there has been a rapid development of pneumatic tube systems. Factors contributing to this development are the necessity for quicker sending of shipments over short distances. A very important thing in some cases is to minimise human factors in case of transport samples of blood or money. In all applications, pneumatic tube systems saves time and money, also increasing job comfort. Time is an important factor, in particular in the case of a hospital (especially at emergency departments), where rapid diagnosis is crucial for saving human life. Today, pneumatic tube systems play a vital role in the development of the healthcare sector. Pneumatic tube systems ensure that qualified personnel do not lose valuable time, e.g. for personal delivery of documents.

Values of minor loss coefficients $\zeta$ for bypass air brake used in contemporary pneumatic tube systems have been calculated, as a part of this article. Loss of flow associated with the 
decrease of air flow velocity and an increase of the difference of static pressure, measured before and after the bypass air brake, are related to the structure of the test element.

In the bypass air brake, losses are associated with locally occurring obstacles, such as elbows, pipe tees, and especially with two one-way valves, which obscure a large part of the cross section of the tubes. These valves induce the biggest losses in the tested air brake. Changing the diameter of the rubber gasket, which is mounted in one-way valve located in transparent part of bypass air brake, induced a significant differences in the static pressure measured before and after the one-way valve. Also, a differences of the air flow velocity has shown a considerable value. The difference of the static pressure has been changed in the range of $64 \mathrm{mmH}_{2} \mathrm{O}$ to $80 \mathrm{mmH}_{2} \mathrm{O}$. Also, the air flow velocity value was significantly reduced by inserting the one-way valve (in range of $25 \mathrm{~m} / \mathrm{s}$, for absence one-way valve, to $5 \mathrm{~m} / \mathrm{s}$ for the case of rubber gasket of diameter $\phi 95 \mathrm{~mm}$ ).

The obtained values of minor loss coefficients $\zeta$ may be helpful for designing contemporary pneumatic tube systems.

There is a serious gap in technical literature in terms of the construction and testing of advanced designs of the pneumatic tube system. The aim of this work is also to partially fill this gap.

\section{References}

[1] Dziechciowski Z., Lorkowski J., Hładki W., Możliwości zmniejszenia kosztów funkcjonowania szpitali przy zastosowaniu poczty pneumatycznej - doniesienie wstępne (The possibilities to reduce hospital costs by using pneumatic tube system - preliminary report), Ostry Dyżur No. 1/2015.

[2] Dziechciowski Z., Czerwiński A., Kozłowski I., Wspótczesne rozwiazania i zastosowania systemów poczty pneumatycznej (Contemporary solutions and applications of pneumatic tube systems), Logistyka No. 6/2014.

[3] Kozłowski I., Construction and research of the laboratory model of pneumatic tube system with autonomous control system, Master Thesis, Cracow University of Technology, Kraków 2015.

[4] Jeżowiecka-Kabsch K., Szewczyk H., Mechanika płynów (Fluid Mechanics), Oficyna Wydawnicza Politechniki Wrocławskiej, Wrocław 2001.

[5] Książek J., Poczta pneumatyczna (Pneumatic post system), Wydawnictwo Komunikacji i Łączności, Warszawa 1971.

[6] Identyfikacja strumienia przeptywu plynów (Identification of the fluid flow), the laboratory script by Cracow University of Technology, Faculty of Mechanical Engineering, Institute of Process and Power Engineering, Department of Fluid Mechanics.

[7] Cichocki W., Michałowski S., Laboratorium systemów transportu bliskiego i urządzeń dźwigowych. Cześć 2. Eksploatacja (Laboratory of handling systems and lifting devices. Part 2. Exploitation), Politechnika Krakowska, Kraków 2012.

[8] PN-76/M-34034 Rurociagi - Zasady obliczeń strat ciśnienia (Pipelines - principles calculations of pressure losses). 